IJAAR IJAAR PUBLISHING ${ }^{\circledR}$

DOI: 10.46654

International Journal of Advanced Academic Research (Social and Management Sciences) | ISSN: 2488-9849

Vol. 6, Issue 8 (August, 2020)|www.ijaar.org

Journal DOI: 10.46654/ij.24889849

Article DOI: 10.46654/ij.24889849.s6810

\title{
COMPETITIVE DYNAMICS AND CORPORATE PROFITABILITY: AN EMPIRICAL ANALYSIS OF ALUMINUM MANUFACTURING FIRMS IN DELTA STATE, NIGERIA
}

\author{
Bayo, Princewill (Ph.D) \\ Lecturer: Department of Management, Faculty of Management Sciences \\ Rivers State University, P.M. 5080, Port Harcourt, Nigeria \\ bayo.princewill@ust.edu.ng ndaabari1968@gmail.com
}

Ebikebena E. Red-well

Graduate Student, Post-Graduate School,

Rivers State University, P.M. 5080, Port Harcourt, Nigeria

redwellemotongha@yahoo.com

\begin{abstract}
The paper examined the relationship between competitive dynamics and corporate profitability in aluminum manufacturing firms in Delta State, Nigeria. The study analyzed data collected from one hundred and ninety-eight (198) senior management staff and managers drawn from six (6) major aluminum and steel manufacturing firms. The study adopts a cross-sectional survey research design. A structured self-made research questionnaire was used to collect data for the study while the multiple regression statistics techniques was used to analyze the study hypotheses at a 95\% confidence interval and 0.05\% level of significance with the aid of Statistical Package for Social Science (SPSS) version 25.0. The reliability of research instrument was obtained through the Crombach's Alpha Coefficients with all the items above 0.70 which was established by Nunnally (1970). The empirical results of the study found a statistically positive and significant relationship between competitive dynamics such as: competitive pricing, new product launch actions and corporate profitability in the aluminum manufacturing firms in Delta State, Nigeria. From the empirical findings, the study concluded that there is a significant relationship between competitive and corporate profitability through competitive pricing and new product launch actions in the industry. Thus, the study recommend that aluminum and steel manufacturing firms should make it a matter of priority to consider competitive pricing moves and new product launch actions to build on their unique competitive advantage so as to increase their level of corporate profitability in the industry.
\end{abstract}

Keywords: Competitive Dynamics, Competitive Pricing, Corporate Profitability 


\section{INTRODUCTION}

The recent increase in globalization of production activities and the changing competitive forces in the aluminum sub-sector of the manufacturing industry have generated stiff competition and have made a good number of firms to wind down their operations in the industry. This giant stride had put corporations at the disadvantaged position and firms are reactive in a bid to sustain their market share and survive (Ferrier, Smith and Grimm, 2001). However, firms are likely to gain a lot of benefits related to increased profitability (Niresh \& Velnampy, 2014). One important precondition for any long-term survival and success of a firm is profitability. It is profitability that attracts investors and the business is likely to survive for a long period of time (Farah \& Nina, 2016). Many firms strive to improve their corporate profitability and they do spend countless hours on meetings trying to come up with a way of reducing operating costs as well as on how to increase their sales (Schreibfeder, 2006).

The study of Eboreime and Adedoyin, (2013) assert that the survival and success of a firm depend on the competitive moves adopted by the firm and relating it with the ever-changing environment where the business operates. The study of Calcagno, (2007) stated that firm profitability depends on firm's quick response to competitive actions and reactions to maintain and sustain in a favorable market position. This position is translated into higher profits compared to those obtained by competitors operating in the same industry. Organizations within the scope of high competitive business environment, requires quality decisions to shape firm's competitive dynamics (Ketchen, Snow and Hoover, 2004), and one of the main issues for managers under firms' business level strategy is the formulation and implementation of competitive actions that would improve the profits base of the organizations to achieve their sustainable goals. The author conceptualized competitive dynamics as the exchange of initiative and responsive actions mediated by the market process. Firms act creatively (introduce a new product, a new promotion, or a new marketing agreement) to enhance or improve profits, to gain industry position (Chen and MacMillan, 1992). Successful actions generate new customers and profits, promote competitive position as rivals attempt to block or imitate the action. The study of competitive dynamics is thus the study of how firm action (moves) affects competitors, in the industry (Burgelman \& Grove, 2007) and sometimes these actions and reactions can escalate among firms so that the industry performance is adversely affected; at other times, the pattern of behavior can be more genteel and profitable.

However, the recent macroeconomic fluctuations on business activities and the rise of new players from peripheral economies, as well as the rapid technology innovation have altered the former competitive behaviour (moves) among businesses (D’Aveni, Dagnino, \& Smith, 2010) and the aluminum sector of the manufacturing industry in Nigeria are in a bid to grasp this surprising changes and respond to threats in order to outsmart their rivals to succeed in the competitive business environment with strong competitive moves. Although, several studies had been done on competitive dynamics in the contexts of banking industry, telecommunication and oil and gas industry in Kenya, Australia, U.S.A and part of Nigeria, German Passenger Transportation industry by (Sascha and Caroline, 2012; Agusto, 2012). A study by Murage (2011) focused on competitive dynamics in the petroleum industry and found a strong influence on profitability, the work of Gathoga (2001) focused on competitive dynamics on commercial banks in Kenya, and Karanja (2002) study found that competitive dynamics had a strong relationship with firm level profit within the real estate firms in the perspective of Porter's 
generic model. Some scholars have examined using different lenses; the findings of Aigboje (2018) revealed that competitive aggressiveness has a significant positive relationship with organizational profitability of hotels in Port Harcourt. Joy, (2013) examined the influence of competitive strategy on organizational performance; using Uni-Lever Plc as a case study.

Considering the limited literatures on this subject matter, it appears that robust scholarly attention has been given to the concept of competitive dynamics in different industries, but from the empirical review less in the manufacturing industry, particularly in Nigeria. Therefore, purpose of this study is to fill this gap in the existing literature by examining the relationship between competitive dynamics and corporate profitability in the aluminum manufacturing firms. The following are the objectives of this study:

1. To examine the relationship between competitive pricing and corporate profitability of aluminum manufacturing firms in Delta State, Nigeria.

2. To examine the relationship between new product launch and corporate profitability of aluminum manufacturing firms in Delta State, Nigeria.

The study also seeks to answer the following research questions:

1. How does competitive pricing affect corporate profitability in the aluminum manufacturing firms in Delta State, Nigeria?

2. How does new product launch affect corporate profitability in the aluminum manufacturing firms in Delta State, Nigeria?

\section{LITERATURE REVIEW Theoretical Review}

The study of competitive dynamics and corporate profitability was domiciled on Penrose's (1959) Resource Based theory. The resource-based theory of the firm (RBT) draws focus to firms' internal environment as an enabler for competitive moves and accentuates the resources that organizations have established to compete in the business environment. The origin of the RBV was trace back to the work of Penrose (1959), who suggested that the resources possessed, deployed and used by the organization are really more important than industry structure. Researchers contributing to the resource-based view contend that only strategically significant and valuable resources and competencies should be regarded as sources of competitive advantage (Barney 1991). They used terms like core competencies (Barney, 1991; Prahalad \& Hamel, 1994), distinctive competencies (Papp \& Luftman, 1995) and strategic assets (Amit \& Shoemaker, 1993; Markides \& Williamson, 1994) to show the strategically important resources and competencies, which provide a firm with a potential competitive edge. Strategic assets are scarce and specialized resources and capabilities that bestow the firm's competitive advantage (Amit \& Shoemaker, 1993). Powell (2001) suggested that business strategy can be regarded as a tool to influence such resources to create competitive advantage. Core competencies are unique, rare, valuable firm level resources that competitors are unable to imitate, substitute or replicate (Barney, 1991; Prahalad \& Hamel, 1994). Distinctive competencies refer to all the things that make the business a success in the marketplace (Papp \& Luftman, 1995). The resource-based view/theory explains the interactions and utilization of the variables of this study, competitive dynamics, pricing actions, and new product launch as drivers of competitive dynamics and profitability. Organizations that effectively leverage on strategically important resources and competencies will provide a firm with a potential competitive edge to outperform competitors. 


\section{Conceptual Review}

\section{Concept of Competitive Dynamics}

The term competitive dynamics has been used in numerous settings, ranging from studies of the competition among classes for survival, to those that are considering how diverse firms compete for supremacy, and to studies pursuing game theoretic models. Competitive dynamics emerged as a powerful concept in the strategic management literature that is concerned with explaining and predicting competitive interactions between rivals and the impact of these interactions on firm performance (Ketchen, David, Snow and Charles, 2004). Competitive dynamics is a study of inter-firm competition founded on explicit competitive moves and responses, their strategic and organizational contexts and their drivers and consequences (Baum \& Korn, 1996; Smith et al., 1992).

Competitive dynamics is defined as a range of actions and responses of firms taking part in a competitive business setting (Chen \& Miller, 1994). According to Marcel, Barr and Duhaime (2010), distinct competitive action becomes the key gauge of competitive dynamics as each organization endorses these actions in order to improve its competitive moves over its competitors. Competitive dynamics refers to the dynamics in the series of initiative and responsive competitive actions among firms in a competitive situation: the study of competitive dynamics is the study of how firm action affects competitors, competitive moves, and performance (Smith, 2001). Accordingly, the key unit of analysis is an individual competitive action. Individual initiative and responsive actions by rival companies, taken together, represent competition in a specific population of firms. The popular conceptualization of competition has been that initiatives actions directly mount competitive pressure on competitors, thereby provoking (Chen and MacMillan, 1992), or inviting (Chen and Miller, 1994; Baum and Korn, 1999) them to respond.

However, competitive response is another phase of competitive dynamics; it is an action taken by a business that is designed to advance a competitive position in the marketplace with the type of competitive actions taken based on the business's strategy (Park, 2011). According to Marcel et al., (2010) the probability of a reaction to an action is contingent on the type of action taken or tactical and the possible consequence on competitors. Since premeditated moves necessitate the use or commitment of definite managerial resources, these are tougher to execute successfully, and are more time consuming and are harder and a lot costly to correct, it is more likely that strategic moves will be executed and responded to more frequently.

\section{Competitive Pricing}

Competitive pricing action is an approach in which a company sells the same product at different prices in different markets. It can also refer to the charging of different prices for the same product to different social or geographic sectors of the market. It describes a way to establish the competitive position in the same industry. Price defines a firm's competitive position in the competitive market and consumers use price to evaluate quality of a brand or retailer (Dolan and Simon, 1996). When many firms are competing for the same consumer with homogeneous product offerings, price defined the competitive position, and is a powerful competitive weapon (Dolan and Simon, 1996; Kotler, 2003). However, if a firm is not accustomed to having to compete on price, it is often hard for the firm to adjust to that notion (Porter, 1998). 
Furthermore, competitive pricing involves setting prices on the basis of the activities of competitors in the industry. Pricing refers to the process of setting price for a product or service, and it is more than any other element in the competitive dynamic literature. Firms using this form of competitive move are sensitive to change in the competitive market. Price for any product or a service will inevitably fall somewhere between that which is too low to produce a profit and that which is too high to generate any demand. Apparently, competitive pricing is the set of actions through which an individual competitive organization by accident or design develops resources and uses them to deliver services or products in a way which its users find valuable, while meeting the financial and other objectives and constraints imposed by key competitors in the industry (Haberberg and Rieple, 2008). In a developing country like Nigeria, with low income and high level of poverty, a firm that wants to succeed should offer its product at the price the consumers can bear. But often, small manufacturers set prices of their products arbitrarily without regard to consumer characteristics in the environment (Ayozie 2008).

\section{New Product Launch}

In the contemporary competitive context, new product introduction takes on a critical role (Tomkovich and Miller, 2000). New products assume a substantial share of a firm's turnover. Firm that fail to react to challengers on the industrial market consistently suffer from market share erosion (Ferrier, Smith and Grimm, 1999). Being able to react quickly and insightfully to competitive moves becomes increasingly important. This is particularly true when these competitive moves represent the introduction of new products, as these really reshape the market. However, firms' competitive analysis constitutes the starting point of many strategy formulation efforts within the firm (Porter, 1980). A new product launch action is partly determined by the reactions and moves of competitors in the industry (Chen, 1996). New product actions provide firms in the manufacturing industry with the opportunity to make them more competitive and productive. Aykan and Ebru (2013) posit that product actions can be distinguished on horizontal and vertical product position. Products are said to be horizontally positioned when consumers, if offered at the same price, would rank them differently showing different preferences for different varieties. Instead, they are said to be vertically positioned if offered at the same price, all consumers choose to buy one of the same, which is the highest quality (Hingley, 2008; White 2000).

Murphy (2007) stated that successful new product launch has three aspects: commanding a premium price for a product, increasing sales because of additional buyers won over by the new modification and gaining buyer loyalty to its brand. Murphy (2007) further stated that product is differentiated if consumers perceive it to have properties, which make it distinct from rival products or services, and ideally unique in some particular way and difficult to emulate. When looking at product differentiation, it is correct to state that it is not given by nature. The main agents behind the introduction of product differentiation are the business firms themselves (Kaleka 2002).

\section{Corporate Profitability}

The word profitability represents the absolute figure of profit but an absolute figure alone does not give an exact idea of the adequacy or otherwise of increase of change in performance as shown in the financial statement of the organization. Corporate profitability is the ability to earn profit from all the activity of an enterprise; it indicates how well management of organizations generates earnings by using the resources at its disposal (Kieso, 2011). In other words, the ability 
to earn profit e.g. corporate profitability is composed of two words- profit and ability. The word ability reflects the power of an organization to earn profit; it is called earning performance. Corporate profitability involves the capacity to make benefits from all the business operations of an organization, firm or company (Muya \& Gathogo, 2016). Profit usually acts as the entrepreneur's reward for his/her investment. However, useful measures of corporate profitability are the rate of return on assets (ROA), operating profit margin, rate of return on equity (ROE), the rate of return on investments (ROl), the rate of return on sales (ROS) and net income. Return on assets is a profitability ratio that measures the net income produced by total assets during a period by comparing net income to the average total assets. Corporate profit is a financial benefit that is realized when the amount of revenue gained from a business activity exceeds the expenses and taxes needed to sustain the activity. According to Brigham and Houston (2009), profitability is the end result of a number of policies and decisions by companies. Kieso (2011) posits profitability ratio is a ratio that illustrates the company's ability to earn a profit through all the existing capabilities and resources such as sales activities, cash, capital, number of employees, number of branches and so on.

\section{Empirical Review}

Gloria and Ding (2005) investigated the mediating effects of a firm's competitive pricing in the market orientation-performance relationship. From a sample of 371 firms in China it was found that the three dimensions of competitive pricing had a direct effect on profitability. This includes price orientation which has the strongest association with competitive pricing and profitability. This lends credence to a component wise approach on the study of the relationship between price orientation and profitability. The findings of Acquaah and Yasai-Ardekani (2008), investigated direct effect of new product viability and profitability of implementing new product introduction, and the combination of the singular strategies. The study found out that incremental performance benefits to firms implementing a combination strategy do not significantly differ from the performance of firms implementing only the new product introduction.

Oyedijo (2012) in his study of competitive strategy orientations of small and medium business owners and their performance impacts: the case of paint manufacturing SMEs in South-Western Nigeria examined the choice of general competitive, trade level strategies by paint manufacturing SMEs in south western Nigeria and their impact on the sales growth, revenue growth, frequency of customer grievances and growth in customer base and observed that product action strategy, low cost strategy and mixed strategy are highly adopted by the sampled paint manufacturing firms and that all of them affect one another in very positive ways. Pimtong, Hanqin and Hailin (2012) investigated the influence of competitive pricing and organizational structure on hotel profitability and to explore whether organizational structure has a moderating effect on the relationship between competitive pricing and the hotel profitability. The results revealed that competitive pricing has a direct effect on hotel behavioral profitability, and a competitive IT strategy to have a direct effect on organization financial performance.

Aigboje (2018) conducted a study of competitive aggressiveness and organizational profitability of Hotels in Port Harcourt, Nigeria. The result of the findings revealed that competitive aggressiveness has a significant positive relationship with organizational profitability of hotels in Port Harcourt. Based on empirical findings, the study concludes competitive pricing influences organizational profitability. Prajogo (2007) examined the underlying strategic intent of product 
quality and the result of his findings show that product quality is predicted by new product launch strategy, but not cost leadership strategy. Mosakowski (1993) findings supported the hypotheses that, when the focus and introducing new product strategies are established, organizational profitability is higher than other firms. The study concluded, there general consensus that there is a positive relationship between new product launch actions and organizational profitability. With these in mind, we are enthused to argue that new product launch actions and reactions and competitive pricing as a dimension of competitive dynamics has the tendency of affecting corporate profitability by proposing that:

Ho: : There is no significant relationship between competitive pricing and corporate profitability in the aluminum firms in Delta State, Nigeria.

Ho$_{2}$ : There is a significant relationship between new product launch and corporate profitability in the aluminum firms in Delta State, Nigeria

The below diagram shows the discussion of the relationship between competitive dynamics with dimensions; competitive pricing, new product launch, and corporate profitability.

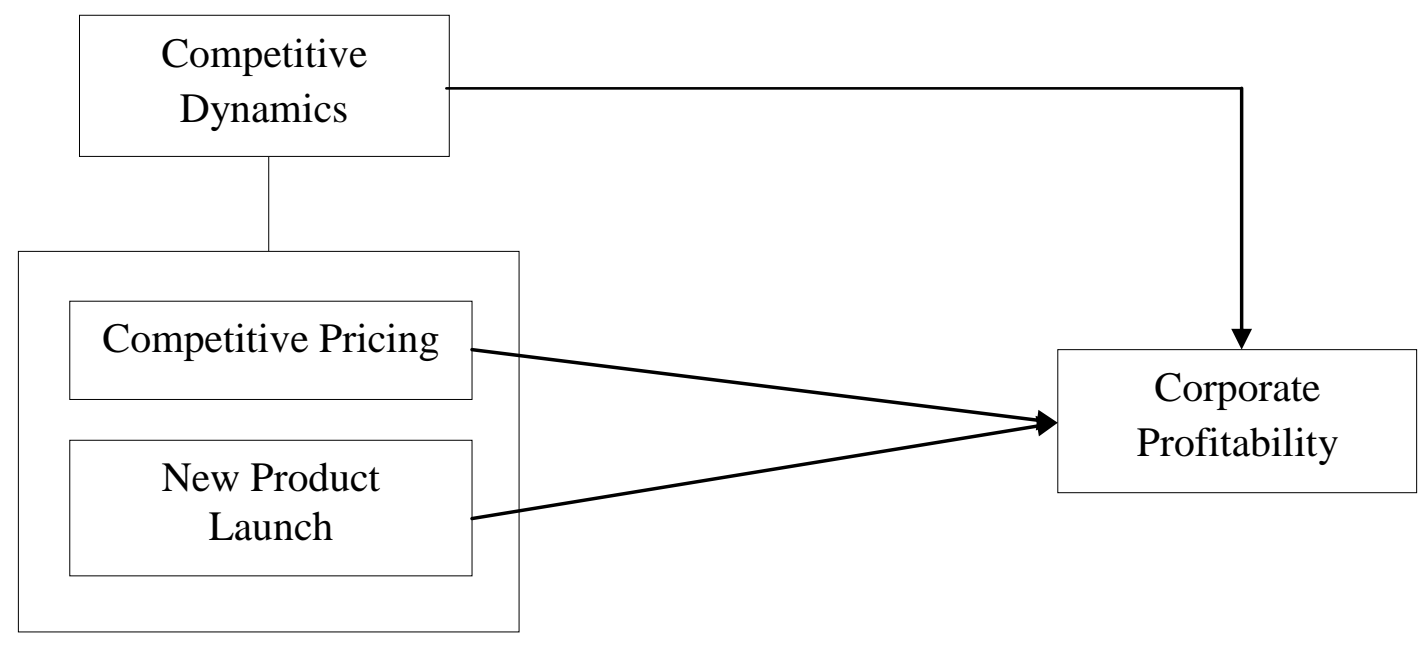

\section{Figure 1: Operational framework indicates competitive dynamics and corporate profitability.}

Source: Author's research work, 2020

\section{METHODOLOGY}

Research design in this study described the fundamental question of how the study will be brought into and what philosophical approach will be employed within the research setting to obtain the required data related to competitive dynamics and corporate profitability. Therefore, the study adopts a cross-sectional survey design in a non-contrive setting and used multiple regression statistics techniques to analyze the study hypotheses at a $95 \%$ confidence interval and $0.05 \%$ level of significance with the aid of statistical package for social science version 25 . The population for the study consists of Aluminum and steel manufacturing firms based in Delta State. The simple random sampling techniques was used to obtained (198) senior management 
staff and managers from (6) six major aluminum and steel manufacturing firms in the manufacturing industry. The study collected primary data through designed questionnaire instruments while the respondents were asked to indicate how they agree or disagree with the items on the questionnaire instrument by ticking from a five (5) point Likert scale (ranging from 1: strongly disagree, 2: disagree, 3: indifferent, 4: agree and 5: strongly agree) was used to measure responses from respondents. The research instrument was subject to face validity by giving experts full copy of the instrument each for their review and critique and they offered good insights and suggestions from their experience. However, the researcher verifies reliability outcomes through confirmatory test of internal consistency on the instrument with a sample using Cronbach Alpha and the threshold level, 0.7 which is generally accepted by the rule of thumb (Nunnally, 1978) was considered adequate with reliability results showed below.

Table 1: Showed the Reliability Analyses

\begin{tabular}{llcc}
\hline S/N & Variables & Cronbach Alpha Results & Number of Cases \\
\hline 1 & Competitive Pricing & 0.980 & 4 \\
2 & New Product Launch & 0.959 & 4 \\
3 & Corporate Profitability & 0.984 & 4 \\
\hline
\end{tabular}

Source: SPSS Output Result

\section{Results and Discussion of Findings Test of Research Hypotheses}

The analysis was carried out using multiple regression analysis at a $95 \%$ confidence interval while the $0.05 \%$ level of significance was adopted as a criterion for the probability of either accepting the null hypothesis at $(\mathrm{p}>0.05)$ or rejecting the null hypothesis at $(\mathrm{p}<0.05)$. We therefore, relied on the regression correlation $(t)$ statistic to undertake the analysis.

\section{The Regression Model showed the effect of Competitive Dynamics (Competitive Pricing,} New Product Launch) on Corporate profitability

\section{Model Summary}

\begin{tabular}{|c|c|c|c|c|}
\hline Model & $\mathrm{R}$ & R Square & Adjusted R Square & Std. Error of the Estimate \\
\hline 1 & $.989^{\mathrm{a}}$ & .879 & .779 & .72138 \\
\hline
\end{tabular}

a. Predictors: (Constant), New Product Launch, Competitive Pricing

The above model showed the linear regression analysis with (R-value 0.989) between the criterion variable (corporate profitability) and the predictor variables competitive dynamics (competitive pricing, new product launch). Therefore, the $(\mathrm{R}$-value $=0.989)$ indicates that there was a positive and strong significant relationship between the criterion variable and the predictor variables in the study. However, the coefficient of determination $\left(\mathrm{R}^{2}\right.$-value 0.879$)$ implies that the predictor variables explain $87.9 \%$ variance of the criterion variable (corporate profitability) while the remaining $12.1 \%$ could be due to the effect of extraneous variables that are not included in the study. 
Table 2: Showed the Multiple Regression Correlation Coefficients Results of Competitive Dynamics (Competitive Pricing, New Product Launch) and Corporate Profitability Coefficients $^{\mathrm{a}}$

\begin{tabular}{|c|c|c|c|c|c|c|}
\hline \multirow{2}{*}{\multicolumn{2}{|c|}{ Model }} & \multicolumn{2}{|c|}{ Unstandardized Coefficients } & \multirow{2}{*}{$\begin{array}{c}\text { Standardized } \\
\text { Coefficients } \\
\text { Beta } \\
\end{array}$} & \multirow[b]{2}{*}{$t$} & \multirow[b]{2}{*}{ Sig. } \\
\hline & & B & Std. Error & & & \\
\hline \multirow[t]{3}{*}{1} & (Constant) & .644 & .155 & & 4.158 & .000 \\
\hline & Competitive Pricing & .668 & .084 & .672 & 7.912 & .000 \\
\hline & New Product Launch & .326 & .087 & .319 & 3.760 & .000 \\
\hline
\end{tabular}

a. Dependent Variable: Corporate Profitability

Source: SPSS 25

\section{Test of Hypothesis 1}

$\mathrm{Ho}_{1}$ : There is no significant relationship between competitive pricing and corporate profitability in the aluminum firms in Delta State, Nigeria.

Table 2a indicates the linear regression correlation coefficient of the study. The relationship between competitive pricing and corporate profitability was statistically positive and significant with ( $t$-statistic value of $7.912>t$-cri. value of 1.96) at a significant level of $(P$-value of $0.000<$ 0.05). Thus, the alternate hypothesis is hereby accepted and stated that there was a significant relationship between competitive pricing and corporate profitability in the aluminum firms in Delta State, Nigeria. However, from the Table $2 \mathrm{a}$, competitive pricing as a predictor variable contributes $(\beta=0.668)$ to the variation of the criterion variable (corporate profitability). This means that competitive pricing makes positive and unique contribution to explain the variation of the criterion variable (corporate profitability) in the study area.

\section{Test of Hypothesis 2}

$\mathrm{Ho}_{2}$ : There is a significant relationship between new product launch and corporate profitability in the aluminum firms in Delta State, Nigeria.

Table $2 \mathrm{~b}$ indicates the linear regression correlation coefficient of the study. The relationship between new product launch and corporate profitability was statistically positive and significant with ( $t$-statistic value of $3.760>t$-cri. value of 1.96$)$ at a significant level of $(P$-value of $0.000<$ 0.05). Therefore, from the empirical result the alternate hypothesis is hereby accepted and restated that there was a positive and significant relationship between new product launch and corporate profitability in the aluminum firms in Delta State, Nigeria. However, from Table $2 b$, new product launch as a predictor variable contributes $(\beta=0.326)$ to the variation of the criterion variable (corporate profitability). This means that new product launch makes a unique contribution to explain the variation of the criterion variable (corporate profitability) in the study area.

\section{Discussion of Findings}

The findings of the study showed that there was a strong and positive significant relationship between competitive pricing and corporate profitability in the aluminum firms in Delta State, 
Nigeria. The findings of the study correspond with the view of Pimtong, Hanqin and Hailin (2012); they concluded that competitive pricing has a direct effect on hotel behavioral profitability, and a competitive IT strategy to have a direct effect on organization financial performance. The findings of Acquaah and Yasai-Ardekani (2008) also established direct effect of new product viability and profitability of implementing new product introduction, and further stated that incremental profits combination strategy does not significantly differ from the performance of firms implementing only the new product introduction. On the nexus between new product launch and corporate profitability, the findings of the study showed that there was a strong statistical positive and significant relationship in both study variables. The study findings are in line with the view of Prajogo (2007) which concluded that product quality is predicted by new product launch strategy, but not cost leadership strategy. The finding also corroborates with Mosakowski's (1993) findings which supported the hypotheses that, when the focus and introducing new product strategies are established, organizational profitability is higher than other firms in the industry.

\section{Conclusion and Recommendations}

The study empirically examined how competitive dynamics relate with corporate profitability in aluminum manufacturing firms in Delta State, Nigeria. From the empirical results and discussion of findings, it was therefore concluded that competitive dynamics had a significant relationship with corporate profitability through competitive pricing and new product launch actions and responses affect corporate profitability in the industry. To this effect, the competitive moves, actions and reactions of rivalry firms were significantly determined by their ability to vary their competitive strategies to achieve desired corporate profitability.

Thus, based on the above findings on the present study, it is therefore recommended that aluminum and steel manufacturing firms that seek to remain in the highly turbulent competitive business environment should make it a matter of priority to consider competitive pricing moves and new product launch actions to build on their unique competitive advantage so as to increase their level of corporate profitability in the industry. 


\section{References}

Acquaah, M. \& Yasai-Ardekani, M. (2008). Does the implementation of a combination competitive strategy yield incremental performance benefits?: A new perspective from a transition economy in Sub-Saharan Africa. Journal of Business Research, 61(2), 123 234

Aigboje. P. O. (2018). Competitive Aggressiveness and Organizational Profitability of Hotels in Port Harcourt, Nigeria. International Journal of Social Sciences and Management Research, 4(5), 37-44.

Agusto, D. (2012). Manufacturing strategy, competitive strategy and firm performance: An empirical study in a developing economy environment. International Journal of Production Economics, 111(2), 122-134.

Amit, R., \& Shoemaker, P. (1993). Specialized assets and organizational rent. Strategic Management Journal, 14(1), 33-47.

Aykan D., \& Ebru, R..C. (2013). Effects of Competitive Strategies and Strategic Management Accounting Techniques on Perceived Performance of Businesses. Australian Journal of Business and Management Research, 3(07), 30-39

Ayozie, D.O. (2008). The Role of Small Scale Industry in National Development in Nigeria. ICAN Students' Journal, 12(1), 10-17.

Barney, J. B. (1991). Firm resources and sustained competitive advantage. Journal of Management, 17 (1), .99-120.

Baum, J. A., \& Korn, H. J. (1996). Competitive dynamics of inter-firm rivalry. Academy of Management Journal, 39(3), 255-255.

Baum, J. A., \& Korn, H. J. (1999). Dynamics of dyadic competitive interaction. Strategic management journal, 20(3), 251-278.

Brigham, E., \& Houston, F. (2009). Fundamentals of Financial Management. South-Western Cengage learning.

Burgelman, R. A., \& Grove, A. S. (2007). Cross-boundary disruptors: powerful inter industry entrepreneurial change agents. Strategic Entrepreneurship Journal, 1(3-4), 315-327.

Calcagno, C. I., (2007). The effect of organic modifier of the clay on morphology and crystallization properties of PET nanocomposites. Polymer, 48(4), 966-974.

Chen, M. J. \& Miller, D. (1994). Sources and consequences of competitive inertia: A study of the US airline industry. Administrative science quarterly, 2(3), 1-23. 
Chen, M. J, \& MacMillan, I. C. (1992). Non-response and delayed response to competitive moves: The roles of competitor dependence and action irreversibility. Academy of Management Journal 35(3), 539-570.

Chen, M. J. (1996). Competitor analysis and interfirm rivalry: Toward a theoretical integration. Academy of Management Review, 21(1), 100-134.

D'Aveni, R. A., Dagnino, G. B., \& Smith, K. G. (2010). The age of temporary advantage. Strategic management journal, 31(13), 1371-1385.

Dolan, R. and Simon, H. (1996). Power Pricing. The Free Press: New York, NY.

Eboreime, O. F., \& Adedoyin, S. A. (2013). Strategies for making competition irrelevant in the global market for developing economies. Journal of Emerging Trends in Economics and Management Sciences, 4 (3) 297-301.

Ferrier, W. J., Smith, K. G. \& Grimm, C. M. (2001). King of the hill: Dethroning the industry leader. Academy of Management Perspectives, 15(2), 59-70.

Ferrier, W. J., Smith, K. G. \& Grimm, C. M. (1999). The role of competitive action in market share erosion and industry dethronement: A study of industry leaders and challengers. Academy of Management Journal 42, (4), 372-388.

Ferrier, W. J. (2001). Navigating the competitive landscape: The drivers and consequences of competitive aggressiveness. Academy of Management Journal 44, (4), 858-877.

Ferrier, W. J, \& Lee, H. (2002). Strategic aggressiveness, variation, and surprise: How the sequential pattern of competitive rivalry influences stock market returns. Journal of Managerial Issues 14, (2), 162-180.

Fisher, M. (1997). What is the right supply chain for your product. Harvard Business Review, 75, (1), 105-116.

Farah, N. S. \& Nina, A. (2016). The Functioning of Inter-modal Competition in the Transportation Market: Evidence from the Entry of Low-cost Airlines in Germany. Review of Network Economics, 8, (2), 189-211

Gathoga, W. (2001). Competitive strategies employed by commercial banks. Unpublished MBA paper University of Nairobi.

Gloria, E. \& Ding, J. N. (2005). Energy efficiency of a manufacturing industry: a case study of Nigeria Eagle Flour Mills Limited, Ibadan. ASSET International Journal, 7(2), 91-103

Hamel, G. \& Prahalad, C. (1994). Competing for the Future. Harvard University Press, Boston. 
Haberberg, A. \& Rieple, A. (2008). Strategic Management Theory and Application. Oxford University Press.

Hingley, M. (2008). Differentiation strategies in vertical channels: A case study from the market for fresh produce. British Food Journal, 110 (1), 42-61.

Joy, S. E. (2013). Market-focused strategic flexibility: Conceptual advances and an integrative model. Academy of Marketing Science Journal, 31(1), 74-97

Kaleka, A. (2002). Resources and capabilities driving competitive advantage in export markets; guidelines for industrial exporters. Journal of Industrial Marketing Management, 31, (1), 273- 283.

Karanja, D. M. (2002). Resistance to reinfection with Schistosoma mansoni in occupationally exposed adults and effect of HIV-1 co-infection on susceptibility to schistosomiasis: a longitudinal study. The Lancet, 360(9333), 592-596.

Ketchen, D. J., Snow, C. C. \& Hoover. V. L. (2004). Research on competitive dynamics: Recent accomplishments and future challenges. Journal of Management, 30, (6), 779-804.

Kieso, D. E. (2011). Intermediate Accounting: Volume 2 Cue. John Wiley.

Kotler, P. (2003). Marketing Management. Prentice-Hall: Upper Saddle River, NJ.

Markides, C. C., \& Williamson, P. J. (1994). Related diversification, core competences and corporate performance. Strategic management journal, 15(S2), 149-165.

Marcel, J. J., Barr, P. S. \& Duhaime, I. M. (2010). The influence of executive cognition on competitive dynamics. Strategic Management Journal, 32(1) 115-138

Mosakowski, E. (1993). A resource-based perspective on the dynamic strategy-performance relationship: An empirical examination of the focus and differentiation strategies. Journal of Management, 19, (2), 24-34.

Murphy, C. A. (2007). Target delineation using full tensor gravity gradiometry data. ASEG extended abstracts, 2007(1), 1-3.

Murage, A. C. (2011). Logistics outsourcing and the supply chain performance of mobile phone service providers in Kenya. Unpublished MBA Project University of Naiobi.

Muya, T. W., \& Gathogo, G. (2016). Effect of working capital management on the profitability of manufacturing firms in NAKURU town, KENYA. International Journal of Economics, Commerce and Management, 4(4), 1082-1105. 
Niresh, A., \& Velnampy, T. (2014). Firm size and profitability: A study of listed manufacturing firms in Sri Lanka. International Journal of Business and Management, 9(4), 223-245

Oyedijo, A. (2012). Effects of product-market diversification strategy on corporate financial performance and growth: An empirical study of some companies in Nigeria. American International Journal of Contemporary Research, 2 (3), 199-210.

Park, J. \& Zhou, D. (2005). Firm heterogeneity and competitive dynamics in alliance formation. Academy of Management Review, 30, (1), 531-554.

Park, J. (2011). Rivalry among existing competitors in the industry. American Research based learning Network, Texas: A\&M University.

Papp, R., \& Luftman, J. (1995). Business and IT Strategic Alignment: New perspectives and assessments, in The Association for Information Systems, Inaugural Americas Conference on Information Systems, Pittsburgh, 25-27.

Penrose, E. (1959). The Theory of the Growth of the Firm. Oxford: University Press, Oxford.

Pimtong, H., Hanqin, G. J. \& Hailin, S. A. (2012). The effect of competitive strategies and organizational structure on hotel performance. International Journal of Contemporary Hospitality Management. 1(2), 345-367.

Prajogo, D. I. (2007). The relationship between competitive strategies and product. Quality Industrial Management and Data Systems, 107, (1), 234-245.

Prahalad, C. K., \& Hamel, G. (1994). Competing for the Future. Boston: Harvard Business School Press.

Porter, M. E. (1985). Competitive Advantage: Creating and Sustaining Superior Performance. Free Press: New York.

Porter, M. E. (1998). Clusters and the New Economics of Competition. Boston: Harvard Business Review.

Powell, W. W. (2001). Competitive advantage: Logical and philosophical considerations. Strategic Management Journal, 22 (9), 875-888.

Sascha, J. \& Caroline, A. (2012). Strategic Flexibility in Product Competition. Strategic Management Journal, 16, (5), 135-159

Smith, L. M. \& Yakhot, V. (1992). The renormalization group, the $\varepsilon$-expansion and derivation of turbulence models. Journal of scientific computing, 7(1), 35-61.

Smith, L. M. (2001). The role of tacit and explicit knowledge in the workplace. Journal of Knowledge Management. 
International Journal of Advanced Academic Research (Social and Management Sciences) | ISSN: 2488-9849

Journal DOI: 10.46654/ij.24889849

Vol. 6, Issue 8 (August, 2020)|www.ijaar.org

Article DOI: 10.46654/ij.24889849.s6810

Tomkovich, S. \& Miller, E. (2000). Intellectual capital and performance in causal models: Evidence from the information technology industry in Taiwan. Journal of Intellectual Capital, 6, (2), 222-236.

White, H. M. F. (2000). Buyer-supplier relationships in the UK fresh produce industry. British Food Journal, 102 (1), 6-17. 